\title{
CASH POSITION, DEBT TO EQUITY RATIO, RETURN ON ASSET DAN FIRM SIZE TERHADAP DIVIDENT PAYOUT RATIO
}

\author{
Edi Setiawan \\ Universitas Muhammadiyah Prof. DR. HAMKA \\ edisetiawan@uhamka.ac.id, \\ Faizal Ridwan Zamzany \\ Universitas Muhammadiyah Prof. DR. HAMKA \\ zamzany@uhamka.ac.id \\ Nur Fitri Amelia \\ Universitas Muhammadiyah Prof. DR. HAMKA \\ nurfitriamelia91@gmail.com
}

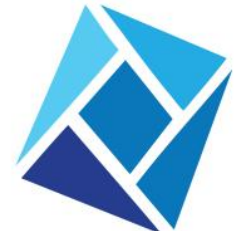

Jurnal Nusantara

Aplikasi Manajemen Bisnis

http://ojs.unpkediri.ac.id/index .php/manajemen/index

E-ISSN : 2528-0929

P-ISSN : 2549 - 5291

Diterima: 31 Maret 2018

Revisi : 16 April 2018

Disetujui: 18 April 2018

httpsdoi.org10.29407nusamba.v3i1. 11980
Abstract

This research is aimed to knowing and analyzing the effect of the cash position, debt to equity ratio, return on asset and firm size to divident payout ratio. The type of data used in this study is pool data which is a combination time series, and cross section. panel data regression anlaysis test, election panel data reression estimation techniques, heteroscedasticity test, regression model analysis, and regression model testin and regression coefficients. The result showed that the partial debt to equity ratio and firm size no significantly influence the divident payout ratio, while the cash position, return on asset significantly influence the divident payout ratio. Simultaneously, cash position, debt to equity ratio, return on asset and firm size variable have a significant to divident payout ratio.

Keywords: Cash position, debt to equity ratio, return on asset, firm size

Abstrak

Tujuan penelitian ini adalah untuk mengetahui dan menganalisis pengaruh Cash position, debt to equity ratio, return on asset dan firm size terhadap divident payout ratio. Metode penelitian yang digunakan adalah desain asosiatif dengan pendekatan kuantitatif. Jenis data yang digunakan dalam penelitian ini adalah data panel yang merupakan gabungan antara data runtut (time-series) dan data silang (cross-section), uji analisis regresi data panel, pemilihan teknik estimasi regresi data panel, uji heteroskedastisitas, analisis model regresi, dan pengujian model regresi dan koefisien regresi. Hasil penelitian menunjukkan bahwa secara parsial debt to equity ratio dan firm size tidak berpengaruh signifikan terhadap divident payout ratio, sementara cash position, return on asset berpengaruh signifikan terhadap divident payout ratio.Secara simultan cash position, debt to equity ratio, return on asset dan firm size berpengaruh signifikan terhadap divident payout ratio.

Kata Kunci: Cash position, debt to equity ratio, return on asset, firm size 


\section{Pendahuluan}

Kebijakan dan pembayaran dividen memiliki pengaruh terhadap pemegang saham dan perusahaan. Para pemegang saham umumnya melihat kestabilan pembayaran dividen merupakan indikator perusahaan untuk dapat dipercaya atau tidak sebagai tempat untuk menanamkan sejumlah dananya atau berinvestasi. Pembayaran dan pembagian dividen yang cenderung stabil dapat mengurangi ketidakpastian para pemegang saham dimana hal ini akan menguntungkan perusahaan itu sendiri karena dengan begitu kemungkinan investor untuk menanamkan dananya dalam perusahaan semakin besar. Perusahaan selalu menginginkan untuk terus tumbuh tanpa mengalami kesulitan memenuhi kewajibannya dalam membayarkan dividen. Perusahaan harus dapat mengalokasikan laba bersihnya dengan bijaksana bukan saja untuk memenuhi kepentingan pemegang saham namun juga untuk menambah nilai perusahaan itu sendiri.

Besar kecilnya dividen yang diberikan perusahaan berbeda-beda tergantung kepada kebijakan yang ada pada perusahaan itu sendiri, sehingga pertimbangan dalam menentukan jumlah atau besarnya pembagian dividen perlu dicermati lebih lanjut. Besarnya persentase dari pendapatan yang akan dibagikan kepada pemegang saham sebagai cash dividen disebut divident payout ratio. Pertimbangan besarnya divident payout ini diduga sangat berkaitan dengan kinerja keuangan perusahaan. Bila kinerja keuangan perusahaan bagus, diharapkan mampu untuk menetapkan besarnya divident payout yang mana besarnya sesuai dengan harapan pemegang saham yaitu mendapatkan dividen dalam jumlah yang besar dan stabil. Kinerja keuangan perusahaan dibaca melalui laporan keuangan, dengan menganalisis rasio keuangan dari laporan keuangan tersebut. (Agus Sartono, 2012).

Beberapa faktor harus dipertimbangkan agar kebijakan dividen yang optimal dapat dicapai dengan tetap memperhatikan kepentingan perusahaan dan pemegang saham. Kebijakan dividen setiap perusahaan berbeda-beda karena faktor prioritas yang dipertimbangkan setiap perusahaan berbeda. Beberapa faktor tersebut diantaranya cash position, debt to equity ratio, return on asset dan firm size merupakan faktor-faktor yang dipertimbangkan dalam optimalisasi kebijakan dividen dalam penelitian ini.

Posisi kas atau likuiditas dari suatu perusahaan merupakan faktor penting yang harus dipertimbangkan sebelum mengambil keputusan untuk menetapkan besarnya dividen yang akan dibayarkan kepada para pemegang saham. Karena dividen merupakan cash outflow, maka makin kuatnya posisi kas atau likuiditas perusahaan berarti makin besar kemampuannya membayar dividen (Kasmir, 2012).

Kebutuhan dana bagi perusahaan merupakan faktor lain yang perlu dipertimbangkan dalam menentukan kebijakan terhadap dividen yang akan diambil. Debt to Equity Ratio (DER) merupakan rasio yang digunakan untuk menilai hutang dengan ekuitas (Kasmir, 2013). Rasio ini berfungsi untuk mengetahui setiap rupiah modal sendiri yang dijadikan sebagai jaminan hutang. Semakin tinggi rasio ini mengindikasikan gejala yang kurang baik, hal ini berarti perusahaan akan lebih mengutamakan untuk membayar pinjamannya daripada membiayai dividen bagi pemegang saham.

\section{KAJIIAN PUSTAKA DAN PENGEMBANGAN HIPOTESIS}

Return On Assets (ROA) menunjukkan kemampuan modal yang diinvestasikan dalam total aktiva untuk menghasilkan laba perusahaan. Semakin tinggi Return On Assets (ROA) maka kemungkinan pembagian dividen juga semakin banyak (Hanafi, 2013). Perusahaan besar dengan total assets yang tinggi dan keuntungan yang cenderung stabil dapat dengan mudah masuk ke pasar modal atau memperoleh bentuk dana lain dari luar untuk pembiayaannnya. Perusahaan yang masuk kriteria seperti ini akan mempunyai tingkat dividen yang lebih tinggi dengan perusahaan kecil atau yang masih baru dengan laba yang masih berfluktuasi. Perusahaan yang besar dan memiliki profitabilitas yang tinggi akan dengan mudah masuk ke pasar modal atau memperoleh dana-dana yang diperlukan untuk perluasan usahanya dibandingkan dengan perusahaan yang masih baru dan kecil (Sundjaja dan Barlian, 2013).

\section{Cash Position}

Kas merupakan aktiva yang paling likuid dan merupakan salah satu unsur modal kerja yang paling 
tinggi tingkat likuiditasnya. Kas adalah seluruh uang tunai yang ada di tangan (cash on hand) dan dana yang disimpan di bank dalam berbagai bentuk, seperti deposito dan rekening koran (Harahap, 2010).

Cash position atau posisi kas merupakan rasio kas akhir tahun dengan laba bersih setelah pajak (earning after tax). Cash position merupakan faktor penting yang harus dipertimbangkan sebelum membuat keputusan untuk menentukan besarnya dividen yang akan dibayar kepada para pemegang saham. Posisi kas yang benar-benar tersedia bagi para pemegangsaham akan tergambar pada free cash flow yang dimiliki oleh perusahaan. Oleh karena dividen merupakan cash outflow, maka makin kuatnya posisi kas (cash position) atau likuiditas bank berarti makin besar kemampuannya membayar dividen (Riyanto, 2012).

\section{Debt To Equity Ratio}

Debt to Equity Ratio (DER) merupakan rasio yang digunakan untuk menilai hutang dengan ekuitas (Sartono,2013). Rasio ini berfungsi untuk mengetahui setiap rupiah modal sendiri yang dijadikan sebagai jaminan hutang, atau dengan kata lain rasio ini menggambarkan sampai sejauh mana modal sendiri perusahaan dapat menutupi hutang-hutangnya kepada pihak luar. Semakin besar rasio ini menunjukkan semakin besar kewajibannya dan rasio yang semakin rendah akan menunjukkan semakin tinggi kemampuan perusahaan memenuhi kewajibannya.

Peningkatan hutang akan mempengaruhi besar kecilnya laba bersih yang tersedia bagi para pemegang saham termasuk dividen yang akan diterima. Apabila perusahaan menentukan bahwa pelunasan hutangnya akan diambil dari laba ditahan, berarti perusahaan harus menahan sebagian besar pendapatannya untuk keperluan tersebut, ini berarti hanya sebagian kecil saja pendapatan yang dapat dibayarkan sebagai dividen. Peningkatan hutang akan mempengaruhi tingkat pendapatan bersih yang tersedia bagi pemegang saham, artinya semakin tinggi kewajiban perusahaan, maka kemampuan perusahaan untuk membagi dividen akan semakin rendah, sehingga DER mempunyai hubungan negatif dengan dividend payout ratio.Hasil penelitian yang dilakukan oleh Triani Pujiastuti (2013).

\section{Return On Asset}

Return on Assets (ROA) adalah rasio antara laba bersih setelah pajak dengan total aktiva (Hanafi, 2013). Rasio ini mengukur keseluruhan keefektifan manajemen dalam menghasilkan laba dengan aktiva yang tersedia. Rasio yang lebih rendah dapat disebabkan karena net profit margin yang rendah atau karena perputaran total aktiva yang rendah. ROA menunjukkan tingkat keuntungan bersih yang diperoleh perusahaan dalam menjalankan operasionalnya.

Semakin besar ROA menunjukkan kinerja perusahaan yang semakin baik karena tingkat pengembalian investasi (return) yang semakin besar. Profitabilitas merupakan kemampuan perusahaan untuk menghasilkan laba pada masa mendatang dan merupakan indikator dari keberhasilan operasi perusahaan. Perusahaan yang mempunyai profitabilitas yang tinggi akan menarik minat investor untuk menanamkan modalnya dengan harapan akan mendapatkan keuntungan yang tinggi pula. Oleh karena dividen diambil dari keuntungan bersih yang diperoleh perusahaan, maka keuntungan tersebut akan mempengaruhi besarnya dividend payout ratio. Perusahaan yang memperoleh keuntungan cenderung akan membayar porsi keuntungan yang lebih besar sebagai dividen. Semakin besar keuntungan yang diperoleh, maka akan semakin besar pula kemampuan perusahaan untuk membayar dividen.

\section{Firm Size}

Ukuran perusahaan (firm size) mencerminkan bahwa perusahaan yang mapan dan besar akan memiliki akses yang lebih mudah ke pasar modal, dibandingkan dengan perusahaan yang masih baru ataupun perusahaan yang kecil (Arifin Z, 2012). Perusahaan yang masih baru ataupun perusahaan yang kecil karena keterbatasan aksesnya ke pasar modal sehinnga kemampuannya untuk mendapatkan modal dan memperoleh pinjaman dari pasar modal juga terbatas. Oleh karena itu maka mereka cenderung untuk menahan labanya guna membiayai operasinya, dan ini berarti dividen yang akan diterima oleh pemegang saham akan semakin kecil. Semakin besar ukuran perusahaan (firm size) maka dividen yang dibagikan juga akan semakin besar, begitu juga sebaliknya. Dengan demikian ukuran perusahaan berpengaruh positif terhadap dividend payout ratio. Ukuran perusahaan diwakili oleh logaritma natural dari total assets. 


\section{METODOLOGI PENELITIAN}

Metodologi penelitian merupakan cara ilmiah untuk mengumpulkan data dengan tujuan dan kegunaan tertentu. Dalam penelitian ini menggunakan desain asosiatif dengan pendekatan kuantitatif, desain asosiatif untuk menganalisis hubungan antara satu satu variabel dengan variabel lainnya atau bagaimana suatu variabel mempengaruhi variabel lain. Metode regresi digunakan untuk mengukur pengaruh variabel independen terhadap variabel dependennya.

\section{Operasional Variabel}

Pada penelitian ini terdapat dua variabel bebas dan satu variabel terikat. Berikut merupakan variabel-variabel yang digunakan dalam penelitian ini.

\section{Cash Position $\left(\mathbf{X}_{1}\right)$}

Posisi likuiditas sebagai pertimbangan besarnya dividen. Merupakan arus kas keluar, semakin kuat CP semakin besar DPR. (Sri Sudarsi, 2012)

$\mathrm{CP}=$ Saldo kas akhir tahun

Laba Bersih setelah pajak

\section{Debt To Equity Ratio ( X2)}

Merupakan rasio hutang terhadap modal. Menggambarkan sejauh mana perusahaan dibiyai oleh hutang. Semakin besar maka kurang baik. (Sartono, 2013).

DER = Total Hutang

\section{Total Modal Sendiri}

Return On Asset (X3)

Kemampuan perusahaan memperoleh laba atas asset yang digunakan. Semakin besar rasio ini maka semakin baik (Hanafi 2013).

ROA = Laba Bersih setelah Pajak

Total Aktiva

\section{Firm Size (X4)}

Mencerminkan ukuran suatu perusahaan dengan hubungannya akses ke pasar modal. Semakin besar maka semakin banyak akses di pasar modal (Arifin Z 2012, Teori Keuangan dan Pasar Modal)

FS= Logaritma natural dari total Asset

\section{Divident Payout Ratio (Y)}

Mencerminkan kemampuan perusahaan membayarkan dividen setiap tahun. (Darmaji dan Fakhruddin, 2012).

DPR= Dividen Kas perlembar Saham

Laba Bersih per lembar saham

\section{HASIL DAN PEMBAHASAN}

\section{Estimasi Regresi Data Panel}

Analisis regresi data panel dapat dilakukan melalui 3 model estimasi, yaitu ordinary least square (common effect), dan model efek tetap (fixed effect). Untuk mengetahui model yang paling sesuai, maka dilakukan beberapa pengujian terlebih dahulu. Berikut akan diuraikan hasil dari ketiga model estimasi tersebut. 
Tabel 1

Ordinary Least Square (Common Effect)

\begin{tabular}{|c|c|c|c|c|}
\hline $\begin{array}{l}\text { Dependent Variable: } \\
\text { Method: Pooled Leas } \\
\text { Date: 02/11/16 Tim } \\
\text { Sample: } 20132015 \\
\text { Included observation } \\
\text { Cross-sections includ } \\
\text { Total pool (balanced) }\end{array}$ & ons: 117 & & & \\
\hline Variable & Coefficient & Std. Error & t-Statistic & Prob. \\
\hline $\mathrm{C}$ & 1.406367 & 0.824443 & 1.705839 & 0.0908 \\
\hline $\begin{array}{c}\text { CP? } \\
\text { DER? } \\
\text { ROA? } \\
\text { FS? }\end{array}$ & $\begin{array}{r}0.037394 \\
0.023441 \\
0.887930 \\
-0.030815\end{array}$ & $\begin{array}{l}0.025813 \\
0.076486 \\
0.428742 \\
0.029164\end{array}$ & $\begin{array}{r}1.448674 \\
0.306475 \\
2.071013 \\
-1.056580\end{array}$ & $\begin{array}{l}0.1502 \\
0.7598 \\
0.0407 \\
0.2930\end{array}$ \\
\hline $\begin{array}{l}\text { R-squared } \\
\text { Adjusted R-squared } \\
\text { S.E. of regression } \\
\text { Sum squared resid } \\
\text { Log likelihood } \\
\text { F-statistic } \\
\text { Prob(F-statistic) }\end{array}$ & $\begin{array}{r}0.145700 \\
0.107218 \\
0.474450 \\
24.98642 \\
-75.70108 \\
3.786192 \\
0.003331\end{array}$ & $\begin{array}{l}\text { Mean dependent var } \\
\text { S.D. dependent var } \\
\text { Akaike info criterion } \\
\text { Schwarz criterion } \\
\text { Hannan-Quinn criter } \\
\text { Durbin-Watson stat }\end{array}$ & & $\begin{array}{l}0.540547 \\
0.502132 \\
1.396600 \\
1.538250 \\
1.454108 \\
1.354310\end{array}$ \\
\hline
\end{tabular}

Sumber: Hasil pengolahan dengan Eviews 7.0

Dengan menggunakan pendekatan ordinary least square, dapat dilihat bahwa hasil adjusted $\mathrm{R}^{2}$ adalah sebesar 0,107218 yang berarti pada model regresi ini, variabel bebas hanya dapat menjelaskan variasi variabel terikat dividend payout ratiosebesar 10,7218 persen sedangkan sisanya 89,3782 persen dijelaskan oleh sebab-sebab lain dari luar model. 
Tabel 2

Model Efek Tetap (Fixed Effect)

\begin{tabular}{|c|c|c|c|c|}
\hline \multicolumn{5}{|c|}{$\begin{array}{l}\text { Dependent Variable: DPR? } \\
\text { Method: Pooled Least Squares } \\
\text { Date: 02/11/16 Time: } 19: 24 \\
\text { Sample: } 2013 \text { 2015 } \\
\text { Included observations: } 3 \\
\text { Cross-sections included: } 39 \\
\text { Total pool (balanced) observations: } 117\end{array}$} \\
\hline Variable & Coefficient & Std. Error & t-Statistic & Prob. \\
\hline $\mathrm{C}$ & 11.53327 & 5.865687 & 1.966227 & 0.0531 \\
\hline $\begin{array}{l}\text { CP? } \\
\text { DER? } \\
\text { ROA? } \\
\text { FS? }\end{array}$ & $\begin{array}{r}0.056479 \\
-0.288129 \\
-4.837361 \\
-0.350817\end{array}$ & $\begin{array}{l}0.020623 \\
0.191181 \\
1.190782 \\
0.202993\end{array}$ & $\begin{array}{r}2.738692 \\
-1.507104 \\
-4.062339 \\
-1.728217\end{array}$ & $\begin{array}{l}0.0077 \\
0.1361 \\
0.0001 \\
0.0882\end{array}$ \\
\hline 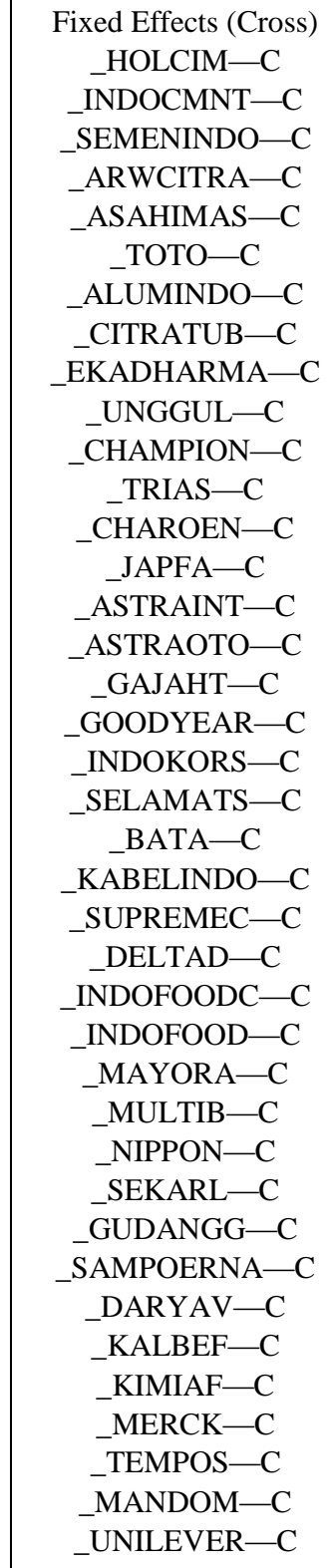 & $\begin{array}{r}0.082896 \\
0.434749 \\
0.702985 \\
-0.368270 \\
-0.824899 \\
-0.587805 \\
-0.209508 \\
0.161319 \\
-1.403605 \\
-0.813239 \\
0.627339 \\
-0.456169 \\
0.519361 \\
0.515762 \\
1.288683 \\
0.079040 \\
-0.276806 \\
-1.027558 \\
0.343742 \\
-0.381305 \\
-0.746749 \\
-1.192320 \\
-0.663954 \\
0.278328 \\
0.231061 \\
0.545538 \\
-0.054091 \\
2.003825 \\
-0.437363 \\
-1.731620 \\
0.569188 \\
2.340155 \\
-0.930607 \\
0.367470 \\
-0.899522 \\
0.255443 \\
-0.218377 \\
-0.676224 \\
2.553108\end{array}$ & & & \\
\hline \multicolumn{5}{|c|}{ Effects Specification } \\
\hline Cross-section fixed (du & iables) & & & \\
\hline
\end{tabular}




\section{JURNAL NUSAMBA VOL.3 NO.1 APRIL 2018}

$\mid \begin{aligned} & \text { R-squared } \\ & \text { Adjusted R-squared } \\ & \text { S.E. of regression } \\ & \text { Sum squared resid } \\ & \text { Log likelihood } \\ & \text { F-statistic } \\ & \text { Prob(F-statistic) }\end{aligned}$

$\begin{array}{ll}0.773698 & \text { Mean dependent var } \\ 0.640397 & \text { S.D. dependent var } \\ 0.301113 & \text { Akaike info criterion } \\ 6.618847 & \text { Schwarz criterion } \\ 2.010977 & \text { Hannan-Quinn criter. } \\ 5.804130 & \text { Durbin-Watson stat } \\ 0.000000 & \end{array}$

0.540547

0.502132

0.717761

1.756527

1.139487

3.586989

Sumber: Hasil pengolahan dengan Eviews 7.0

Dengan menggunakan model efek tetap, dapat dilihat bahwa hasil adjusted $\mathrm{R}^{2}$ lebih tinggi dibanding menggunakan model ordinary least square yaitu sebesar 0,640397 yang berarti pada model regresi ini, variabel bebas dapat menjelaskan variasi variabel terikat dividend payout ratio sebesar 64,0397 persen sedangkan sisanya 35,9603 persen dijelaskan oleh sebab-sebab lain dari luar model.

\section{Pemilihan Teknik Estimasi Regresi Data Panel}

Uji Chow, digunakan untuk memilih antara model OLS (Common Effect) yang tidak menggunakan variabel dummy atau Fixed Effect.

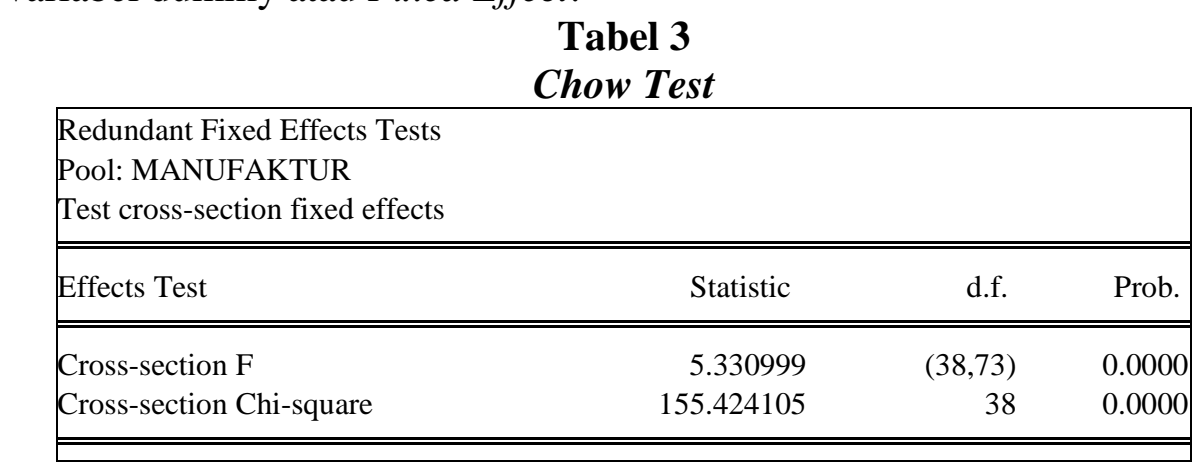

Sumber: Hasil pengolahan dengan Eviews 7.0

Berdasarkan hasil uji Chow Test yang ditunjukkan pada Tabel 3 dapat dilihat bahwa nilai probabilitas F-test dan chi-square lebih kecil dari $\alpha=0,05(5 \%)$, sehingga $\mathrm{H}_{0}$ ditolak dan $\mathrm{H}_{1}$ diterima, yang berarti pendekatan estimasi model mengikuti model efek tetap.

Uji Hausman digunakan untuk memilih estimasi yang paling tepat antara pendekatan fix effect di dalam regresi data panel:

Tabel 4

Hausman Test

\begin{tabular}{lllll|}
\hline $\begin{array}{l}\text { Correlated Random Effects - Hausman Test } \\
\text { Pool: MANUFAKTUR } \\
\text { Test cross-section random effects }\end{array}$ & & \\
\hline \hline Test Summary & Chi-Sq. Statistic & Chi-Sq. d.f. & Prob. \\
\hline \hline Cross-section random & 26.674847 & 5 & 0.0001 \\
\hline \hline
\end{tabular}

Sumber: Hasil pengolahan dengan Eviews 7.0

Hasil Hausman test menunjukkan nilai probabilitas Chi-Square sebesar 0,0001 <alpha $(0,05)$. Dengan demikian $\mathrm{H}_{1}$ diterima, sehingga model mengikuti efek tetap. Atau dapat disimpulkan bahwa model efek tetap lebih baik daripada model efek random dalam mengestimasi regresi data panel.

Tabel 5

Hasil Pemilihan Model Regresi

\begin{tabular}{|c|c|c|}
\hline Metode & Pengujian & Hasil \\
\hline Chow Test & $\begin{array}{c}\text { OLS vs Efek } \\
\text { Tetap }\end{array}$ & Metode Efek Tetap \\
\hline Hausman Test & Efek Tetap & Metode Efek Tetap \\
\hline Lagrange Multiplier Test & OLS & - \\
\hline
\end{tabular}

Sumber: Hasil pengolahan dengan Eviews 7.0 
Dapat dilihat bahwa pemilihan model terbaik untuk mengestimasi data panel adalah menggunakan metode efek tetap (fixed effect). Hal tersebut terlihat dari hasil kedua metode untuk pengujian yang menghasilkan metode efek tetap di dalam Chow Test dan Hausman Test. Uji Lagrange Multiplier Test tidak dilakukan.

Uji Heteroskedastisitas ini digunakan untuk menguji apakah ada tidaknya kesamaan varians dari residual satu pengamatan ke pengamatan lain. Model dikatakan mengandung heteroskedastisitas apabila varian residual dan error tidak konstanta

\section{Tabel 6}

Hasil Uji Heteroskedastisitas

\begin{tabular}{|llll|}
\hline Heteroskedasticity Test: White & & & \\
\hline \hline F-statistic & 1.327365 & Prob. F(5,111) & 0.2578 \\
Obs*R-squared & 6.600895 & Prob. Chi-Square(5) & 0.2521 \\
Scaled explained SS & 34.46183 & Prob. Chi-Square(5) & 0.0000 \\
\hline
\end{tabular}

Sumber: Hasil pengolahan dengan Eviews 7.0

Dari tabel diatas dapat dijelaskan bahwa data penelitian tidak terkena masalah heteroskedastisitas, hal ini dapat dilihat dari nilai Prob.Chi-Square yang melebihi taraf signifikan sebesar 5\% (0.05).

\section{Analisis Model Regresi}

Merupakan alat yang digunakan untuk menentukan persamaan regresi yang menunjukkan hubungan antara variabel terikat yang ditentukan dengan dua atau lebih variabel bebas. Tujuan utama analisis regresi adalah untuk perkiraan nilai suatu variabel (terikat) jika nilai variabel lain yang berhubungan dengannya (variabel bebas) sudah ditentukan. Pengukuran statistik deskriptif dalam penelitian ini dilakukan dengan menggunakan program komputer "Eviews".

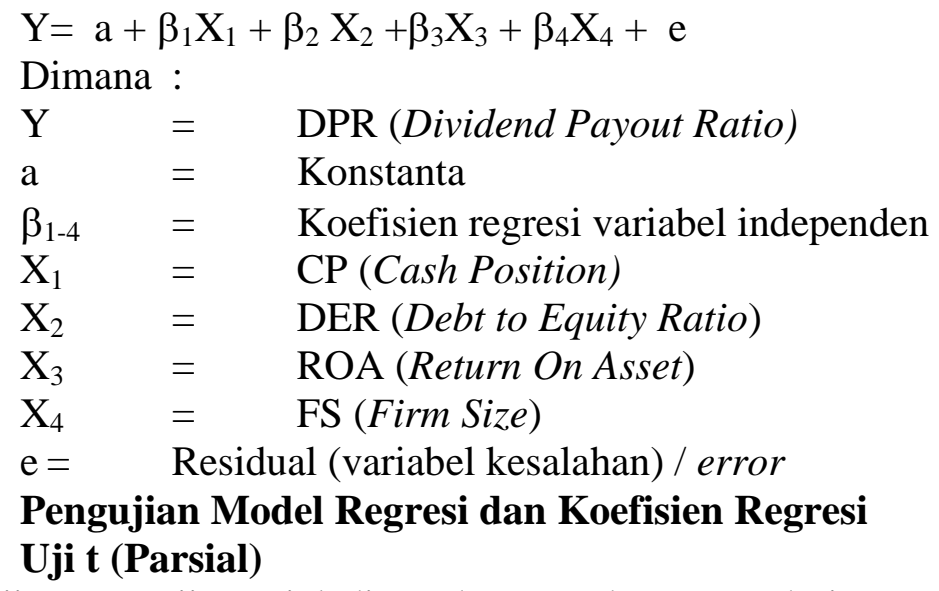

Uji t atau uji parsial digunakan untuk mengetahui pengaruh variabel independen secara individu terhadap variabel dependen. Suatu variabel independen dikatakan memiliki pengaruh signifikan terhadap variabel dependen jika nilai probabilitas masing-masing variabel bebas $(p$-value $)<\alpha$.

Cash Position (CP)

Dengan menggunakan pendekatan Fix Effect dapat dilihat bahwa nilai Probilitas untuk variabel Cash Position adalah $0.0077<0,05$ karena $p$ Value $<0,005$ maka H1 diterima artinya Cash Position berpengaruh signifikan terhadap Divident Payout Ratio

Debt To Equity Ratio ( DER)

Bahwa nilai Probilitas untuk variabel Debt To Equity Ratio adalah 0.1361 sehingga $>0,005$ karena $P$ value $<0,005$ maka H0 ditolak, artinya Debt To Equity Ratiotidakberpengaruh signifikan terhadap Divident Payout Ratio.

Return On Asset (ROA)

Bahwa nilai Probilitas untuk variabel Return On Assetadalah 0.0001 sehingga $>0,005$ karena $P$ value<0,005 maka H1 diterima, artinya Return On Assetberpengaruh signifikan terhadap Divident Payout Ratio.

Firm Size (FS) 
Bahwa nilai Probilitas untuk variabel Firm Sizeadalah $0.0882>0,005$ karena $P$ value $<0,005$ maka HO ditolak artinya Firm Size tidak berpengaruh signifikan terhadap Divident Payout Ratio.

Ketentuan: Jika $p$-value $<\alpha$, maka $\mathrm{H}_{0}$ ditolak

\section{Tabel 7}

Hasil Uji t

\begin{tabular}{|ccccc|}
\hline Variable & Coefficient & Std. Error & t-Statistic & Prob. \\
\hline \hline & & & & \\
CP? & 0.056479 & 0.020623 & 2.738692 & 0.0077 \\
DER? & -0.288129 & 0.191181 & -1.507104 & 0.1361 \\
ROA? & -4.837361 & 1.190782 & -4.062339 & 0.0001 \\
FS? & -0.350817 & 0.202993 & -1.728217 & 0.0882 \\
& & & & \\
\hline
\end{tabular}

Sumber: Hasil pengolahan dengan Eviews 7.0

Dari tabel diatas hanya variabel CP dan ROA yang mempunyai nilai probabilitas lebih kecil dari nilai $\alpha=5 \%$ yang berarti variabel CP dan ROA berpengaruh signifikan terhadap DPR, sedangkan variabel independen lainnya yaitu DER,dan FS tidak berpengaruh signifikan terhadap DPR

\section{Uji F ( Simultan)}

Uji $\mathrm{F}$ atau uji simultan digunakan untuk menguji pengaruh variabel independen secara bersamasama terhadap variabel dependen. Adapun hipotesis pada uji $\mathrm{F}$ adalah sebagai berikut:

$\mathrm{H}_{0}$ : CP, DER, ROA,dan FS secara bersama-sama tidak berpengaruh signifikan terhadap DPR. $\mathrm{H}_{\mathrm{a}}$ : CP, DER, ROA,dan FS secara bersama-sama berpengaruh signifikan terhadap DPR.

Ketentuan: prob (F-statistic) $<\alpha$, maka $\mathrm{H}_{0}$ ditolak.

\section{Tabel 8}

\section{Uji F ( Simultan)}

\begin{tabular}{|llll|}
\hline R-squared & 0.773698 & Mean dependent var & 0.540547 \\
Adjusted R-squared & 0.640397 & S.D. dependent var & 0.502132 \\
S.E. of regression & 0.301113 & Akaike info criterion & 0.717761 \\
Sum squared resid & 6.618847 & Schwarz criterion & 1.756527 \\
Log likelihood & 2.010977 & Hannan-Quinn criter. & 1.139487 \\
F-statistic & 5.804130 & Durbin-Watson stat & 3.586989 \\
Prob(F-statistic) & 0.000000 & & \\
\hline
\end{tabular}

Sumber: Hasil pengolahan dengan Eviews 7.0

Dari hasil uji F diperoleh nilai prob (F-statistic) sebesar 0,000000. Dengan menggunakan alpha 0,05, dapat dijelaskan bahwa dikarenakan prob (F-statistic) lebih kecil dari 0,05 (5\%), maka $\mathrm{H}_{0}$ ditolak dan $\mathrm{H}_{\mathrm{a}}$ diterima. Jadi, dapat disimpulkan bahwa CP, DER, ROA, dan FS secara bersamasama berpengaruh signifikan terhadap DPR.

\section{Uji Koefisien Determinasi}

Koefisien determinasi $\left(\mathrm{R}^{2}\right)$ digunakan untuk melihat persentase pengaruh variabel independen terhadap variabel dependen

Tabel 9

Hasil Uji Koefisien Determinasi

Adjusted R-squared $\quad 0.640397$

Sumber: Hasil pengolahan dengan Eviews 7.0

Berdasarkan nilai adjusted $\mathrm{R}^{2}$ adalah sebesar 0,640397, dapat diartikan bahwa variabel-variabel bebas dalam penelitian ini yaitu CP, DER, ROA, dan FS dapat menjelaskan variasi variabel terikatDPR sebesar 64,0397 persen. Sedangkan sisanya, yaitu sebesar 35,9603 persen, dijelaskan oleh variabel-variabel lain di luar model penelitian. 
Dari hasil pembahasan dan analisis mengenai pengaruh cash position, debt to equity ratio, return on asset dan firm size terhadap divident payout ratio pada perusahaan manufaktur, maka dapat disimpulkan bahwa variabel cash position, debt to equity ratio, return on asset, dan firm size, berpengaruh signifikan terhadap variabel dependen dividend payout ratio secara simultan. Hanya variabel cash position dan return on asset yang berpengaruh signifikan terhadap variabel dependen dividend payout ratio secara parsial, sedangkan variabel debt to equity ratio, dan firm size, tidak berpengaruh.

Hasil penelitian menunjukkan hanya 2 dari 4 variabel bebas yang memiliki pengaruh signifikan secara parsial, oleh karena itu untuk pembaca dan penelitian selanjutnya disarankan untuk menambah dan menggunakan variabel bebas lainnya dalam mengestimasi dividend payout ratio. Dengan keterbatasan penelitian yang mencakup periode 2013-2015 saja, disarankan agar menggunakan periode yang lebih banyak, jenis periode yang berbeda, serta menggunakan sampel yang lebih banyak dan kriteria yang berbeda. Untuk investor dan perusahaan (emiten), terkait dengan penelitian ini variabel cash position dan Return On asset mungkin dapat dijadikan acuan sebagai bahan pertimbangan dalam mengambil keputusan berinvestasi atau kebijakan dividen.

\section{DAFTAR PUSTAKA}

Arifin. Z. (2012). Teori Keuangan Dan Pasar Modal. Yogyakarta: Ekonesia.

Barlian \& Sundjaja. (2013). Manajemen keuangan pendekatan matematis. Jakarta: PT. Gramedia Pustaka Utama.

Fakhruddin \& Darmaji. (2012). Analisis laporan keuangan (Edisi Tujuh). Jakarta: Erlangga.

Hanafi. (2013). Analisis laporan keuangan. Yogyakarta: UPP STIM YPKN

Harahap. (2010). Analisis kritis atas laporan Keuangan. Jakarta: Rajawali Persada.

Kasmir. (2012). Analisis Lapora Keuangan. Jakarta: PT. Raja Grafindo Persada. . (2013). Analisis Laporan Keuangan. (Edisi Satu) Cetakan Ke 6. Jakarta: Rajawali Pers.

Pujiastuti, Triani. (2013). Biaya Agensi terhadap Kebijakan Dividen pada Perusahaan Go Public di Indonesia. Jurnal Keuangan dan Perbankan, Vol.12 No.2.

Riyanto .(2012). Dasar-Dasar Pembelanjaan Perusahaan. (Edisi 4). Yogyakarta: Yayasan Penerbit Gajah Mada.

Sartono, Agus. (2012). Manajemen Keuangan Teori dan Aplikasinya. (Edisi Empat). Yogyakarta: BPFE.

Sartono. (2013). Manajemen Keuangan Teori \& Aplikasinya. Yogyakarta: BPFE.

Sudarsi, Sri. (2012). Manajemen Keuangan. (Edisi Tiga). Jakarta: Mitra Wacana 